\title{
Fermentation by lactic acid bacteria at two temperatures of pre-heated reconstituted milk. I - Behaviour of proteins and minerals
}

\author{
Anne LALIGANT ${ }^{\mathrm{a}}$, Marie-Hélène FAMELART ${ }^{\mathrm{a} *}$, Gérard BRULÉ $^{\mathrm{b}}$, \\ Michel PIOT ${ }^{\mathrm{a}}$, Denis PAQUET ${ }^{\mathrm{c}}$ \\ a Laboratoire de Recherches de Technologie Laitière, INRA, 65 rue de Saint-Brieuc, \\ 35042 Rennes Cedex, France \\ b ENSAR, 65 rue de Saint-Brieuc, 35042 Rennes Cedex, France \\ c Danone Vitapole Recherche, RD 128, 91767 Palaiseau Cedex, France
}

(Received 24 January 2002; accepted 20 November 2002)

\begin{abstract}
The $\mathrm{pH}$-induced physico chemical changes in a reconstituted heated $\left(90{ }^{\circ} \mathrm{C}-10 \mathrm{~min}\right)$ skim milk were studied during fermentation by lactic acid bacteria at two temperatures $\left(30^{\circ} \mathrm{C}\right.$ and $42{ }^{\circ} \mathrm{C}$ ). Different variables were examined during acidification: the water content of ultracentrifugation pellets $\left(150000 \mathrm{~g}\right.$ for $70 \mathrm{~min}$ at 30 or $\left.42{ }^{\circ} \mathrm{C}\right)$, the partition of proteins into pelleted and unpelleted fractions (analysed by RP-HPLC on supernatants) and the dissociation of colloidal salts (determined by atomic absorption spectrophotometry on the ultrafiltrates). The proportion of unpelleted protein was found to be $\mathrm{pH}$-dependent with a gradual linear decrease during acidification. All the caseins pelleted below $\mathrm{pH}$ 5.5. As the $\mathrm{pH}$ was reduced, calcium was progressively released from the micelles. In contradiction with a number of previous findings, fermentation induced a shift toward acid $\mathrm{pH}$ values of the salt dissociation compared with a glucono-delta-lactone acidification. The partition of casein between the pellet and the supernatant due to acidification by fermentation was temperature-dependent, as was the solvation of the pellet. Both were greater at $30{ }^{\circ} \mathrm{C}$ compared with $42{ }^{\circ} \mathrm{C}$. The temperature had no effect on the salt distribution. The results are discussed in terms of transfer phenomena between the colloidal and the solvent fractions and diffusion-limited processes.
\end{abstract}

Milk / yoghurt / pH / mineral / micellar solvation / casein

Résumé - Fermentation du lait reconstitué traité thermiquement par des bactéries lactiques à deux températures. I - Protéines et minéraux. L'effet $\mathrm{du} \mathrm{pH}$ sur les évolutions physicochimiques de lait écrémé reconstitué et traité thermiquement à $90^{\circ} \mathrm{C}, 10 \mathrm{~min}$ a été étudié au cours d'une acidification par fermentation lactique à deux températures $\left(30^{\circ} \mathrm{C}\right.$ et $\left.42^{\circ} \mathrm{C}\right)$. La quantité d'eau a été évaluée par séchage des culots d'ultracentrifugation ( $150000 \mathrm{~g}$ pendant $70 \mathrm{~min}$ à $30 \mathrm{ou} 42^{\circ} \mathrm{C}$ ). La distribution des protéines entre le culot et le surnageant a été analysée par chromatographie RPHPLC sur les surnageants avec ou sans dithiothreitol. La dissociation des sels colloïdaux a été déterminée par spectrométrie d'absorption atomique dans les ultrafiltrats de lait. La proportion de protéines dans le surnageant était dépendante du $\mathrm{pH}$ avec une diminution graduelle au cours de

* Correspondence and reprints

Tel.: (33) 02-23-48-53-22; fax: (33) 02-23-48-53-50; e-mail: famelart@ rennes.inra.fr 
l'acidification. La majorité des caséines était culottée vers $\mathrm{pH}$ 5,5. Au cours de l'acidification, il y a une dissociation progressive du calcium colloïdal. La température est sans effet sur les équilibres minéraux. Comparée à l'acidification par la glucono-delta-lactone, la fermentation induit un décalage vers des $\mathrm{pH}$ plus acides de la dissociation des sels colloïdaux. La répartition de la caséine entre le culot et le surnageant, tout comme la teneur en eau des culots, est fonction de la température de fermentation et augmente à $30^{\circ} \mathrm{C}$ par rapport à $42{ }^{\circ} \mathrm{C}$. La baisse de la température accroît les concentrations de caséines non centrifugées, particulièrement autour de $\mathrm{pH}$ 6,0. Ces résultats sont discutés en terme de phénomènes de transfert entre le solvant et la fraction colloïdale et de limitation par la diffusion.

\section{Lait / yaourt / pH / minéraux / hydratation / caséine}

\section{INTRODUCTION}

The physicochemical changes in proteins during acidification of unheated skim milk, performed either by organic/mineral acid or glucono-delta-lactone (GDL) addition to milk have been studied for a very long time. As the $\mathrm{pH}$ decreases, the solubility of calcium phosphate increases, leading to its dissociation from the micelle, and the negative charge of ionised groups decreases, leading to the dissociation of calcium from phosphoserine residues [13, 19, 20, 29]. A small proportion of casein dissociates from the micelle, with a maximum at $\mathrm{pH} 5.5$, and reassociates at lower $\mathrm{pH}[12,19,29]$. The micelle diameter decreases until $\mathrm{pH} 5.0$ and then sharply increases as the gelation proceeds $[4,8]$. The $\zeta$-potential, the voluminosity and the solvation of the casein micelle decrease, often with a maximum around $\mathrm{pH} 5.5$ (or 5.1 for the potential) $[3,12,13]$. Around $\mathrm{pH} 4.6$, if the acidification has been performed quiescently, a viscoelastic gel is produced, as in yoghurt manufacture.

In fact, the quality of yoghurt is strongly dependent on the heat treatment of milk prior to acidification. Heat treatment is given for hygienic considerations, but mostly for textural or fundamental rheological point of view. It is well known that heating milk at temperatures $\geq 80^{\circ} \mathrm{C}$ leads firstly to a shorter time of gelation and to an increased $\mathrm{pH}$ value at gelation, and secondly to a great increase in the storage modulus [14]. The shape of the $\tan \delta$ versus time or versus $\mathrm{pH}$ in acidified heated milk is very different from the one obtained from unheated milk, with a "maximum in $\tan \delta$ " between $\mathrm{pH} 5.3$ and 5.0, while no maximum is found with unheated milk [21-23].

It is well known that heat treatment of milk induces many changes in proteins. After a heat treatment at $80{ }^{\circ} \mathrm{C}$ for $5 \mathrm{~min}$, a denaturation of $74 \%$ of $\beta$-lactoglobulin $(\beta-\mathrm{LG})$ and of $58 \%$ of $\alpha$-lactalbumin ( $\alpha$-LA) is observed. Only $58 \%$ and $40 \%$ of these denatured proteins associate with casein micelles, respectively [29]. The behaviour of $\alpha$-LA and $\beta$-LG are dependent upon the time of heating, the temperature, the $\mathrm{pH}$ and the amount of proteins [5, 25]. After heating at $85^{\circ} \mathrm{C}$ for $10 \mathrm{~min}$, a marked increase in the concentration of $\kappa$-casein $(\kappa-\mathrm{CN})$ in the supernatant has been reported (from 15 in unheated to $23 \%$ of total $\kappa-\mathrm{CN}$ in heated milk) [18], but it should be noted that increasing the $\mathrm{pH}$ value to 7.1 leads to a greater concentration of supernatant casein in the milk heated to $70-80{ }^{\circ} \mathrm{C}$ [2]. Above $80^{\circ} \mathrm{C}$, at $\mathrm{pH} 7.1$, the proportion of $\kappa-\mathrm{CN}$ in the supernatant increases, while that of $\alpha_{S}-\mathrm{CN}\left(\alpha_{S 1}+\alpha_{S 2}\right)$ decreases [2].

Moreover, the role of micro-organisms is not limited to acid production. Indeed, micro-organisms can play a role, firstly with their enzymatic potential and secondly because they produce acid only in the solvent permeate. This can lead to heterogeneity in the acid production and to a $\mathrm{pH}$ gradient. The acid production by microorganisms proceeds very differently from 
what happens with GDL, as GDL is soluble in milk and can diffuse quickly in the solvent permeate and through the casein micelle. Bacteria generally grow in large colonies in milk and are weakly mobile, so that the local $\mathrm{pH}$ value around the bacteria is more acidic than in the bulk [11]. Microorganisms are probably rapidly blocked into a microscopic gel area, so that the acid production is more and more confined within small areas. With micro-organisms, lactic acid is produced merely in the solvent permeate.

The aim of this series of articles is a better understanding of the construction of yoghurt, from materials close to the manufacture, i.e. with heat-treated milk acidified by lactic acid starters. In this paper, the static point of view is presented: the partition of cations and proteins between the solvent and the colloidal fractions and the water content of the pelleted proteins. The dynamic point of view will be presented in the next article, including direct rheological and physicochemical measurements during acidification.

\section{MATERIALS AND METHODS}

\subsection{Milk}

Milk was reconstituted at $11 \%$ solid content (casein $33.3 \mathrm{~g} \cdot \mathrm{kg}^{-1}$ ) with the same batch of a low-heat skim milk powder $(\mathrm{WPNI}=8.0)$ (Ingredia, Arras, France) in MilliQ water. The composition of the reconstituted milk is presented in Table I. After $1 \mathrm{~h}$ equilibrium at room temperature, the milk was heat-treated in a spiral stainless steel tube of $6 \mathrm{~mm}$ internal diameter immersed in a thermostatically controlled water bath. The flow rate of milk through the system was approximately $3.5 \mathrm{~L} \cdot \mathrm{min}^{-1}$ and the residence volume of the loop was $180 \mathrm{~mL}$. Milk samples $(0.5 \mathrm{~L}$ or $1 \mathrm{~L})$ were held at $90{ }^{\circ} \mathrm{C}$ for $10 \mathrm{~min}$. Immediately after heating, the milk was quickly cooled by immersion in ice-cold water with a gentle motion. The heating profile was monitored
Table I. Chemical composition of the reconstituted milk at $11 \%$ total solids used for the manufacture of yoghurt, before the heat treatment. The percents of proteins were calculated from the HPLC analysis.

\begin{tabular}{lc}
\hline & $\begin{array}{c}\text { Unheated milk } \\
\left(\mathrm{g} \cdot \mathrm{L}^{-1}\right)\end{array}$ \\
\hline Dry matter & 110.0 \\
Ashes & 9.39 \\
Total nitrogen $(\mathrm{TN}){ }^{*}(1)$ & 38.97 \\
Non-casein nitrogen $(\mathrm{NCN}){ }^{*}(2)$ & 7.72 \\
Non-protein nitrogen $(\mathrm{NPN}){ }^{*}(3)$ & 2.11 \\
Total proteins $(\mathrm{TN}-\mathrm{NCN}) *^{*}$ & 36.86 \\
Whey proteins $(\mathrm{NCN}-\mathrm{NPN}) *^{*}$ & 5.61 \\
$-\alpha$-lactalbumin $* *$ & 1.0 \\
$-\beta$-lactoglobulin $* *$ & 3.4 \\
Total casein $(\mathrm{TN}-\mathrm{NCN}) *$ & 31.25 \\
$-\kappa^{*}$-asein $* *$ & 3.0 \\
$-\alpha_{\mathrm{S} 1}$-casein $* *$ & 12.6 \\
$-\alpha_{\mathrm{S} 2}$-casein $* *$ & 2.5 \\
$-\beta$-casein $* *$ & 12.2 \\
\hline
\end{tabular}

* From Nitrogen determination; ** from HPLC determination; (1) using 6.38 as converting factor; (2) using 6.25 as converting factor; (3) using 6.19 as converting factor.

with a thermocouple placed inside the bottle. Warm-up time of 1-2 min was taken into account for the calculation of the heating time. After heating, there was a slight drop in $\mathrm{pH}$ (0.05 unit).

Each batch of milk was divided into equal portions of $100 \mathrm{~g}$ in capped sterile glass vials filled to the top to prevent air incorporation and stored at $4{ }^{\circ} \mathrm{C}$.

\subsection{Yoghurt gels}

Set yoghurts were produced with a mixed culture of non-ropy Streptococcus thermophilus and Lactobacillus delbrueckii subsp. bulgaricus provided by Danone and inoculated in milk at $10^{7} \mathrm{CFU} \cdot \mathrm{mL}^{-1}$ each.

Fermentation temperatures were $30^{\circ} \mathrm{C}$ and $42{ }^{\circ} \mathrm{C}$, considered, respectively, as a slow and a rapid acidification. The milk sample $(100 \mathrm{~g})$ was equilibrated for $1 \mathrm{~h}$ at the fermentation temperature in a water 
bath before inoculation with the culturediluted ferments.

Inoculated milk was quiescently incubated at the fermentation temperature until pH 4.0 was achieved. The kinetics of acidification were registered for $20 \mathrm{~h}$ using a Cinac system (Ysebaert, Frépillon, France) [32]. Fermentation at each temperature was carried out in duplicate, the day of the heat treatment and the following day. Changes in physical properties as a function of $\mathrm{pH}$ are mean values.

Three different preparations of milk at 30 and $42{ }^{\circ} \mathrm{C}$ were realised so that 6 kinetics of acidification were obtained.

\subsection{Acidification by GDL}

Unheated and heated milk samples with $0.2 \mathrm{~g} \cdot \mathrm{kg}^{-1} \mathrm{Na}$ azide added were transferred into 10 vials of $50 \mathrm{~mL}$ and stored at $30{ }^{\circ} \mathrm{C}$. GDL (Merck Eurolab, Fontenay-sousBois, France) was added to each sample at final concentrations ranging from 0.56 to $22 \mathrm{~g} \cdot \mathrm{L}^{-1}$ to reach $\mathrm{pH}$ values from 6.64 to 4.05 in $17 \mathrm{~h}$ at $30^{\circ} \mathrm{C}$. Acidified milk samples were then stirred and the analysis of minerals in the permeates obtained, as described in the 2.4.2.1 section, at each final $\mathrm{pH}$ value, was performed.

\subsection{Analyses}

\subsubsection{Unheated milk}

Total solids content was obtained at $103^{\circ} \mathrm{C}$ for $7 \mathrm{~h}$ using an air-oven by drying duplicate samples under atmospheric conditions [15]. Milk ash was determined according to the method described by the AOAC [1]. The nitrogen content was determined from $\mathrm{N}$ analysis by the Kjeldahl method using a Kjeltec digestion system (Técator, Foss France, Nanterre, France). Fractionation of total nitrogen (NT) in the milk was according to the Rowland procedure for non-casein nitrogen $(\mathrm{NCN})$ and for non-protein nitrogen (NPN) [28]. The converting factors were $6.38,6.25$ and 6.19 , respectively, for NT, NCN and NPN.
The whey protein and casein concentrations were determined as NCN-NPN and TN-NCN. Individual proteins were analysed using HPLC.

\subsubsection{Acidified milk}

Acidified milk samples were examined after fractionation in terms of pelleted casein and diffusible salts. Water content of the pellet materials was also determined. The acidification was stopped by addition of $2.05 \mathrm{~g} \cdot \mathrm{L}^{-1}$ sodium azide at specific $\mathrm{pH}$ values, i.e. at $\mathrm{pH}$ 6.0, 5.5, 5.0 and 4.6. Immediately after the addition of azide, the milk was gently stirred at room temperature and fractionated. The initial $\mathrm{pH}$ represents the observations taken immediately after the inoculation of the milk followed by azide addition.

\subsubsection{Fractionation of acidified milk}

The milk permeate was obtained by ultrafiltration on membranes of $25 \mathrm{~kg} \cdot \mathrm{mol}^{-1}$ molecular mass cut-off (Centriflo CF 25, Amicon, Grace, Épernon, France) for the determination of diffusible salts. Ultrafiltration in the centrifuge was carried out at the appropriate temperature $\left(42{ }^{\circ} \mathrm{C}\right.$ or $30{ }^{\circ} \mathrm{C}$ ) at $750 \mathrm{~g}$ for $45 \mathrm{~min}$.

The sedimentation of proteins was performed by centrifugation at $150000 \mathrm{~g}$ for 70 min at $42{ }^{\circ} \mathrm{C}$ or $30^{\circ} \mathrm{C}$. The separation was carried out using a L8-55 ultracentrifuge with a 50.2 Ti rotor (Beckman Instruments France S.A., Gagny, France). Supernatants and pellets were separated by gently pouring out the supernatant and were analysed for the unpelleted and the pelleted fractions.

\subsubsection{Analyses of acidified milk}

Total $\left(\mathrm{Ca}_{\mathrm{T}}, \mathrm{Mg}_{\mathrm{T}}, \mathrm{Na}_{\mathrm{T}}, \mathrm{K}_{\mathrm{T}}\right)$ and diffusible cation concentrations were determined by atomic absorption spectrometry using Varian equipment (Les Ulis, France) on milk and milk permeate, respectively, according to Le Graet and Brulé [20]. Duplicate measurements on 2 different 
samples of milk were performed at each temperature.

Casein analysis was performed on milk and on the supernatant by reversed-phase high-performance liquid chromatography (RP-HPLC) on 2 different samples of milk.

The determination of the water content was done on the pellet on 2 different samples. Drained pellets were weighed and dried at $103{ }^{\circ} \mathrm{C}$ for $7 \mathrm{~h}$. Water content of the pellet was expressed as grams of water per gram of dry pellet. As in the literature, when the water contents of the pellet are expressed per gram of proteins, the current values will be underestimated. The pellets were mainly composed of casein micelles, plus some denatured whey proteins and minerals and bacterial cells. A bacteria cell represents $10^{-12} \mathrm{~g}$ and $2 \times 10^{-13} \mathrm{~g}$, on a moisture and dry basis respectively. During fermentation, bacteria grow from $10^{6}$ to $10^{9} \mathrm{CFU} \cdot \mathrm{mL}^{-1}$. The weight of bacteria in the pellet only changes the 1000th of the water content and was neglected.

\subsubsection{RP-HPLC}

The protein composition of unheated and heat-treated milk and in corresponding supernatants was determined by RP-HPLC on a Waters 600 delivery system, a 481 variable wavelength LC spectrophotometer and a 740 data module (Waters, Milford, MA, USA). Elution was performed in duplicate on a $\mathrm{C}_{4}$ Vydac 214 TP 54 column (Touzart \& Matignon, Vitry-sur-Seine, France) $(15 \mathrm{~cm} \times 4.6 \mathrm{~mm}$ i.d., $5 \mu \mathrm{m}$ particle size), maintained at $40{ }^{\circ} \mathrm{C}$.

This method was adapted from [16] and [36]. The solvent A was $0.1 \%(\mathrm{~V} / \mathrm{V})$ trifluoroacetic acid (TFA) in water and solvent $\mathrm{B}, 0.096 \%(\mathrm{~V} / \mathrm{V})$ TFA in $80 \%(\mathrm{~V} / \mathrm{V})$ acetonitrile. The initial mobile phase was $46 \%$ solvent B. After equilibration of the column with $46 \% \mathrm{~B}$, samples (50 or $200 \mu \mathrm{L}$ ) were loaded onto the column. Proteins were eluted at a flow rate of $1 \mathrm{~mL} \cdot \mathrm{min}^{-1}$, using a linear gradient of solvent $\mathrm{B}$ as follows: $0-15 \mathrm{~min}, 46-61 \%$; 15-17 min, 61-100\%; 17-22 min 100\%;

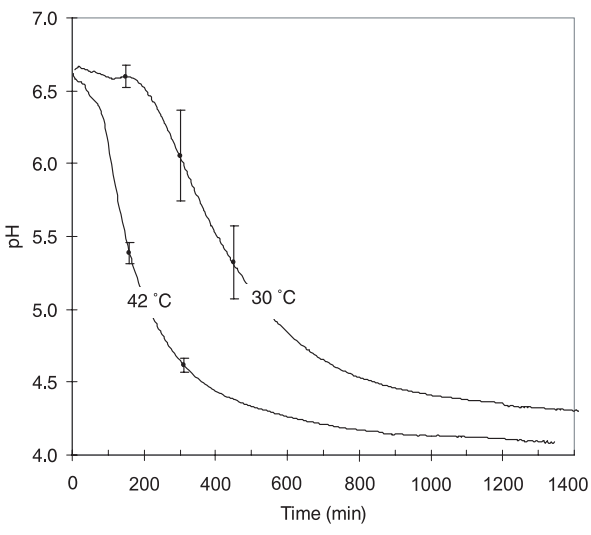

Figure 1. Kinetics of milk acidification with lactic acid bacteria at 30 and $42{ }^{\circ} \mathrm{C}$.

22-24 min, 100-46\%; 24-34 min, 46\%. The elutes were quantified for protein by measuring the absorbance at $280 \mathrm{~nm}$.

The method enabled the evaluation of concentrations with a coefficient of variation of $5 \%$.

The milk and supernatant were respectively diluted $1 / 10$ and $1 / 2$ in $8 \mathrm{~mol} \cdot \mathrm{L}^{-1}$ urea buffer, $1 \mathrm{~mol} \cdot \mathrm{L}^{-1}$ Tris $/ \mathrm{HCl}$, Na-Citrate $13 \mathrm{~g} \cdot \mathrm{L}^{-1}, \mathrm{pH}$ 7.0. This buffer allowed reduction of the proteins in the presence of dithiothreitol (DTT). Under reducing conditions, milk samples with $\sim 10 \mathrm{mg}$ protein $\cdot \mathrm{mL}^{-1}$ were treated with $10 \mathrm{mmol} \cdot \mathrm{L}^{-1}$ DTT and incubated for $1 \mathrm{~h}$ at $37^{\circ} \mathrm{C}$. Samples were diluted $1 / 2$ in solvent $A$ and then filtered through a $0.45 \mu \mathrm{m}$ filter prior to injection. Thus, milk samples and supernatants were diluted twenty-fold and fourfold, respectively.

\section{RESULTS AND DISCUSSION}

\subsection{Kinetics of milk acidification during fermentation}

The $\mathrm{pH}$ kinetics are shown in Figure 1. The confidence intervals were greater at 30 than at $42{ }^{\circ} \mathrm{C}$. The maximal rate of acidification at $42{ }^{\circ} \mathrm{C}$ was twice that at $30{ }^{\circ} \mathrm{C}$, say 0.9 and $0.4 \mathrm{pH}$ unit. $\mathrm{h}^{-1}$, respectively. 


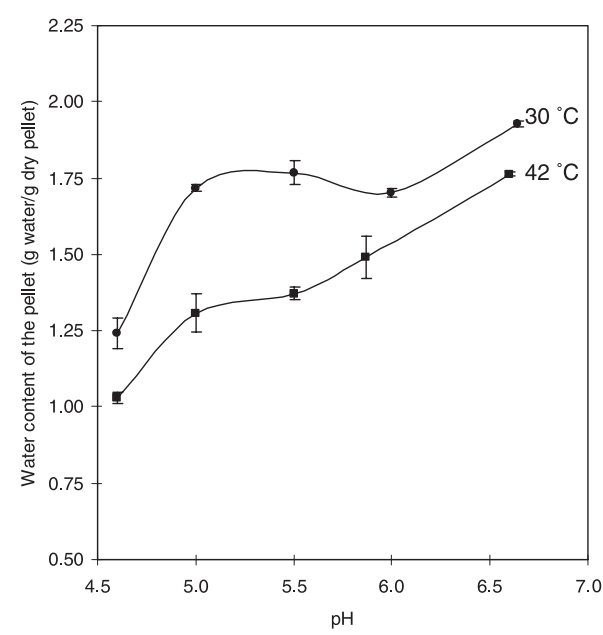

Figure 2. Water content of the ultracentrifugation pellet $(150000 \mathrm{~g}$ for $70 \mathrm{~min}$ at 30 or $42^{\circ} \mathrm{C}$ ) expressed in $\mathrm{g}$ of water/g dry pellet upon acidification of heated skim milk by fermentation at $30{ }^{\circ} \mathrm{C}(\bullet)$ or $42{ }^{\circ} \mathrm{C}(\boldsymbol{\square})$. Means are plotted with $95 \%$ confidence interval indicated by vertical bars for 2 determinations.

The lag times and the times needed to reach $\mathrm{pH}$ values such as $5.5,5.0$ or 4.6 were reduced as the temperature increased. At $42{ }^{\circ} \mathrm{C}$, the final $\mathrm{pH}$ at $20-24 \mathrm{~h}$ was close to 4.0-4.2. It slightly increased to 4.3 at $30{ }^{\circ} \mathrm{C}$. Fermentation at $30{ }^{\circ} \mathrm{C}$ produced slower rates of acid development and of gel formation, for the same final $\mathrm{pH}$ value.

\subsection{Water content of the pellet}

Figure 2 shows the relationship between the $\mathrm{pH}$ and the water content of the pellet. At initial $\mathrm{pH}$ (6.7) and $30^{\circ} \mathrm{C}$, the water content of the pellet was $1.9 \mathrm{~g} \mathrm{H}_{2} \mathrm{O}$ per $\mathrm{g}$. As predicted by equations of thermodynamics, the water sorption by proteins decreases with increasing temperature [17]. But, as in Snoeren et al. [30], the centrifugation force was not corrected between 30 and $42{ }^{\circ} \mathrm{C}$ for the differences in viscosity. The water content of the pellet decreased during acidification. There was a plateau near $\mathrm{pH}$ 5.0-5.5, more pronounced at 30 than at $42{ }^{\circ} \mathrm{C}$. Previous studies on acidification obtained with GDL or $\mathrm{HCl}$ at 20 or
$30{ }^{\circ} \mathrm{C}$ reported the same pattern for micelle solvation versus $\mathrm{pH}$ curves, a maximum or a shoulder, around pH 5.4 [30, 31, 33, 35]. However, Vreeman [37] did not observe this behaviour.

The water content of the pellet during acidification remained higher at $30^{\circ} \mathrm{C}$ than at $42{ }^{\circ} \mathrm{C}$. The difference between the water content at 30 and $42{ }^{\circ} \mathrm{C}$ was not constant over the total range of $\mathrm{pH}$. It was minimum near $\mathrm{pH} 6.0$ ( $0.20 \mathrm{~g}$ water/g dry pellet $)$ and became maximal between $\mathrm{pH} 5.5$ and 5.0 with a value of $0.50 \mathrm{~g}$ water/g dry pellet.

The same changes in water content of the pellet fraction as a function of $\mathrm{pH}$ appeared in heated milk compared with unheated: as the net negative charge of casein was reduced, the affinity for water decreased, but around $\mathrm{pH}$ 5.0-5.5, the micelle swelled, or some casein left the micelle and was replaced by water.

\subsection{Diffusible salts}

Figure 3 shows the extent of transfer of $\mathrm{Ca}$ from the micelle to the serum as a function of the $\mathrm{pH}$. The changes in diffusible $\mathrm{Mg}$ were similar to $\mathrm{Ca}$. The dissociation of colloidal $\mathrm{Ca}$ with the $\mathrm{pH}$ decrease showed two distinct stages: first, above $\mathrm{pH} 6.0$ with a slight increase in concentration $(10.3 \%$ of $\mathrm{Ca}_{\mathrm{T}}$ ), then below pH 6.0, with an extensive increase $\left(57.6 \%\right.$ of $\left.\mathrm{Ca}_{\mathrm{T}}\right)$. At $\mathrm{pH} 4.6$, calcium is almost entirely diffusible at $42{ }^{\circ} \mathrm{C}$ and at $30^{\circ} \mathrm{C}$. Le Graet and Brulé [20] suggest that calcium is entirely diffusible at $\mathrm{pH} 3.5$.

At initial $\mathrm{pH}$, potassium and sodium were present almost entirely as free ions in milk. Nevertheless, their levels seemed to increase very slightly as $\mathrm{pH}$ decreased (results not shown).

The concentration of diffusible Ca shown in Figure 3 is lower compared with that described in the literature for unheated reconstituted milk, under acidification either by $\mathrm{HCl}$ or GDL addition $[3,7,10$, $12,18,20,35]$. Acidification by GDL of unheated or heated milk released calcium differently compared with the fermented 


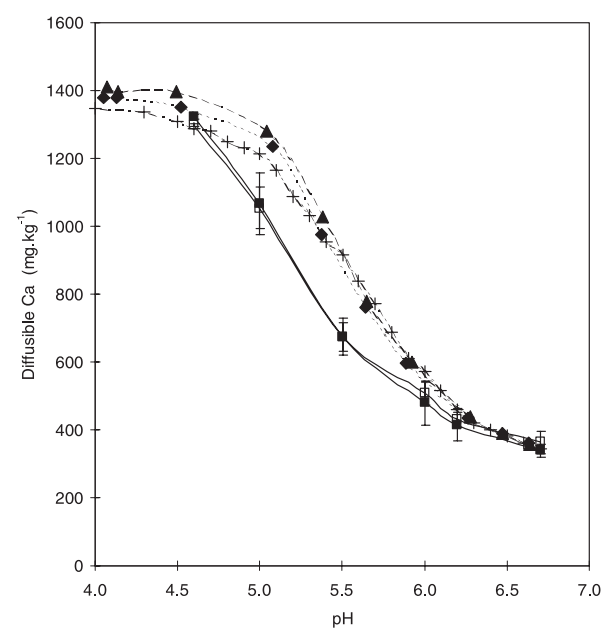

Figure 3. Concentration of diffusible calcium upon acidification by addition of glucono delta lactone at $30{ }^{\circ} \mathrm{C}$ in unheated milk $(\boldsymbol{\Delta})$, in milk heat-treated at $90^{\circ} \mathrm{C}$ for $10 \mathrm{~min}(\bullet)$ or by fermentation at $30{ }^{\circ} \mathrm{C}(\square)$ or $42{ }^{\circ} \mathrm{C}(\boldsymbol{\square})$ in milk heat-treated at $90{ }^{\circ} \mathrm{C}$ for $10 \mathrm{~min}$. Diffusible salts are determined in the permeates obtained by ultrafiltration on Centriflo CF25. For each temperature, values are the means of 4 assays. Ninety-five \% confidence intervals are indicated by vertical bars. Cross symbols are values from a curve published by Le Graet et al. [17] at room temperature.

sample (Fig. 3). From the initial pH down to $\mathrm{pH}$ 6.0, the dissociation of colloidal calcium was completely superimposable with that in the fermented sample. Then, between pH 6.0 and 5.0, acidification by GDL led to a greater dissociation. Experiments at $30{ }^{\circ} \mathrm{C}$ and $42{ }^{\circ} \mathrm{C}$ showed a similar salt partition with acidification. Heat treatment of milk from 70 to $90{ }^{\circ} \mathrm{C}$ for $5 \mathrm{~min}$ or $85^{\circ} \mathrm{C}$ for $10 \mathrm{~min}$ has little effect on the dissociation of calcium and Pi from the micelle [18, 29].

These results cannot be due to a different affinity of lactic acid for the calcium than gluconic acid, as the pK of these acids are not so different ( $\mathrm{pK}$ of lactic acid $=3.8$; $\mathrm{pK}$ of gluconic acid = 3.6, [24]). Anyway, dissociation of colloidal calcium with $\mathrm{HCl}$ is rather close to that obtained with gluconic acid and that of lactic acid is different, and the affinities of lactic and gluconic acid for calcium are probably closely related and are very different from that obtained with a strong acid such as $\mathrm{HCl}$.

These results led to the conclusion that fermentation induced a shift towards lower $\mathrm{pH}$ values of the concentration of diffusible Ca. As a matter of fact, Le Graet et al. [20] have used $\mathrm{HCl}$ at $30^{\circ} \mathrm{C}$ and studied only the final state, which means when chemical equilibrium is complete. Law and Leaver [19] tested the effect of the rate of acidification in the presence of $\mathrm{HCl}$ or GDL on the dissociation of colloidal calcium phosphate $(\mathrm{CCP})$ at $20{ }^{\circ} \mathrm{C}$ : the extent of dissociation of CCP was dependent on the $\mathrm{pH}$ of milk, but was not significantly affected by the time that was required to reach the $\mathrm{pH}$ or by the mode of acidification.

The mode of acidification may also modify the salt dissociation. It has been proved that the production of lactic acid by bacteria led to low local $\mathrm{pH}$ values. Growth of Lactococcus lactis inoculated at low level $\left(10^{2} \mathrm{CFU} \cdot \mathrm{mL}^{-1}\right)$ shows evidence, through visual observation of the colour of a $\mathrm{pH}$ indicator, that the acids diffuse rather slowly in liquid milk around bacteria grouped in macro-colonies [11]. Thus, the micelle interface is probably at a $\mathrm{pH}$ value susceptible to aggregation or gelation. At the same time, the inner part is still at high $\mathrm{pH}$ and highly mineralised, because of the high buffering capacity of the phosphate groups. The micelle can present a $\mathrm{pH}$ gradient from the inner to the outer part. It may even be possible that the layer of gelled whey proteins and caseins on the particle surface of heated milk acidified by lactic acid bacteria could hinder the dissociation of colloidal salts.

Protons produced during acidification are immediately bound by phosphate and citrate, whose $\mathrm{pK}$ are higher than the $\mathrm{pK}$ of lactic acid. The transfer of these acids inside the casein micelle can be hindered by steric or electrostatic tensions, as these acids are negatively charged. It is not only $\mathrm{H}^{+}$that must diffuse, but $\mathrm{H}^{+}$together with 
these acids. These phenomena, which are dependent on diffusion processes, can lead to a rather different kinetics and behaviour, when considering the protein environment.

The fact that, between $\mathrm{pH} 6.6$ and 6.0, the quantity of diffusible calcium was equivalent between fermented milk and chemically acidified milk (Fig. 3) can be explained as follows: in this $\mathrm{pH}$ range, the dissociation of colloidal calcium phosphate is only induced by the acidification of the solvent phase and, consequently, is due to the increase in the solubility of CCP. No diffusion limitation occurred in this transfer. Under $\mathrm{pH}$ 6.0, the dissociation of the calcium from phosphoserine takes place only if citric and phosphoric acids and $\mathrm{H}^{+}$can diffuse into the micelle, and we assumed this step to be dependent on the mode of acidification.

\subsection{Changes in protein status}

\subsubsection{Initial heat-treated milk (results not shown)}

The amount of proteins in the supernatant was $15 \%$ of total proteins in unheated milk and decreased to $5 \%$ in heat-treated milk. They were whey proteins along with a small quantity of casein: 3 and 5\% of total casein in unheated and heat-treated milk are present in this fraction, respectively. Heating at $90{ }^{\circ} \mathrm{C}$ for $10 \mathrm{~min}$ produced total denaturation of $\beta$-LG, whereas $12 \%$ of residual $\alpha$-LA was found in the heat-treated milk. The HPLC profile of the supernatant showed a new broad peak, eluted behind $\beta-\mathrm{LG}$, which was dissociated into 4 peaks in the presence of DTT. As this peak was DTT-sensitive, it probably contained whey protein aggregates. As a matter of fact, heat treatments higher than $70{ }^{\circ} \mathrm{C}$ provoke an extensive denaturation of $\alpha$-LA and $\beta$-LG [29]. Heating at $80{ }^{\circ} \mathrm{C}$ for 5 min induces the association of $58 \%$ of total $\beta$-LG with casein micelles, while $74 \%$ of $\beta-\mathrm{LG}$ is denatured [29].

Due to the heat treatment, an increase of $13 \%$ in the $\mathrm{pH} 4.6$-insoluble protein content
(NT-NCN) and a decrease of $75 \%$ in the concentration of whey proteins $(\mathrm{NCN}$ NPN) were found in milk, expressed as a percentage of that in unheated milk.

The increase in unpelleted casein by heating was mainly due to an enrichment of the supernatant in $\kappa-\mathrm{CN}$. The ratio of unpelleted $\kappa-\mathrm{CN}$ to total $\kappa-\mathrm{CN}$ was $6-7 \%$ in unheated milk and increased to $30-40 \%$ in heated milk, as previously reported [2, $18,34]$.

\subsubsection{Acidified milk}

\subsubsection{Whey proteins}

The denatured whey protein present in the unpelleted fraction, accounting for about $1.3 \mathrm{~g} \cdot \mathrm{L}^{-1}$ of protein nitrogen and supposed to constitute the broad peak in HPLC of the unpelleted fraction of heated milk treated with DTT (Fig. 5B) decreased rapidly as the $\mathrm{pH}$ was lowered. This result is in accordance with the isoelectric $\mathrm{pH}$ value of 5.3 for $\beta-L G$, which is the major whey protein. At $30{ }^{\circ} \mathrm{C}$, in heated milk $\left(85^{\circ} \mathrm{C}-10 \mathrm{~min}\right)$, the serum concentrations of denatured whey proteins become negligible below pH 5.5 [18].

\subsubsection{Casein}

Fermentation of heated milk at $30{ }^{\circ} \mathrm{C}$ or $42{ }^{\circ} \mathrm{C}$ resulted in a regular and linear decrease in the concentration of casein in the supernatant as the $\mathrm{pH}$ decreased from 6.7 to 5.5 (Fig. 4). Unpelleted casein disappeared completely between pH 5.5 and 5.0 at both temperatures (Fig. 5A), but not at $\mathrm{pH}$ values currently expected, such as 4.1 , $5.3,4.5$ and 4.1 which are values of isoelectrical $\mathrm{pH}$ for $\alpha_{\mathrm{S} 1}, \alpha_{\mathrm{S} 2}, \beta$ and $\kappa-\mathrm{CN}$, respectively [9]. In fact, due to the complexation of whey proteins with $\kappa-\mathrm{CN}$, presumptions can be made that the casein micelle behaved during acidification as the outer layer of whey proteins. The isoelectric $\mathrm{pH}$ of $\alpha-\mathrm{LA}$ and $\beta-\mathrm{LG}$ is 5.1 and 5.3, respectively [27].

Law [18] observed similar trends at $30{ }^{\circ} \mathrm{C}$ in milk heat-treated at $85^{\circ} \mathrm{C}$ for 

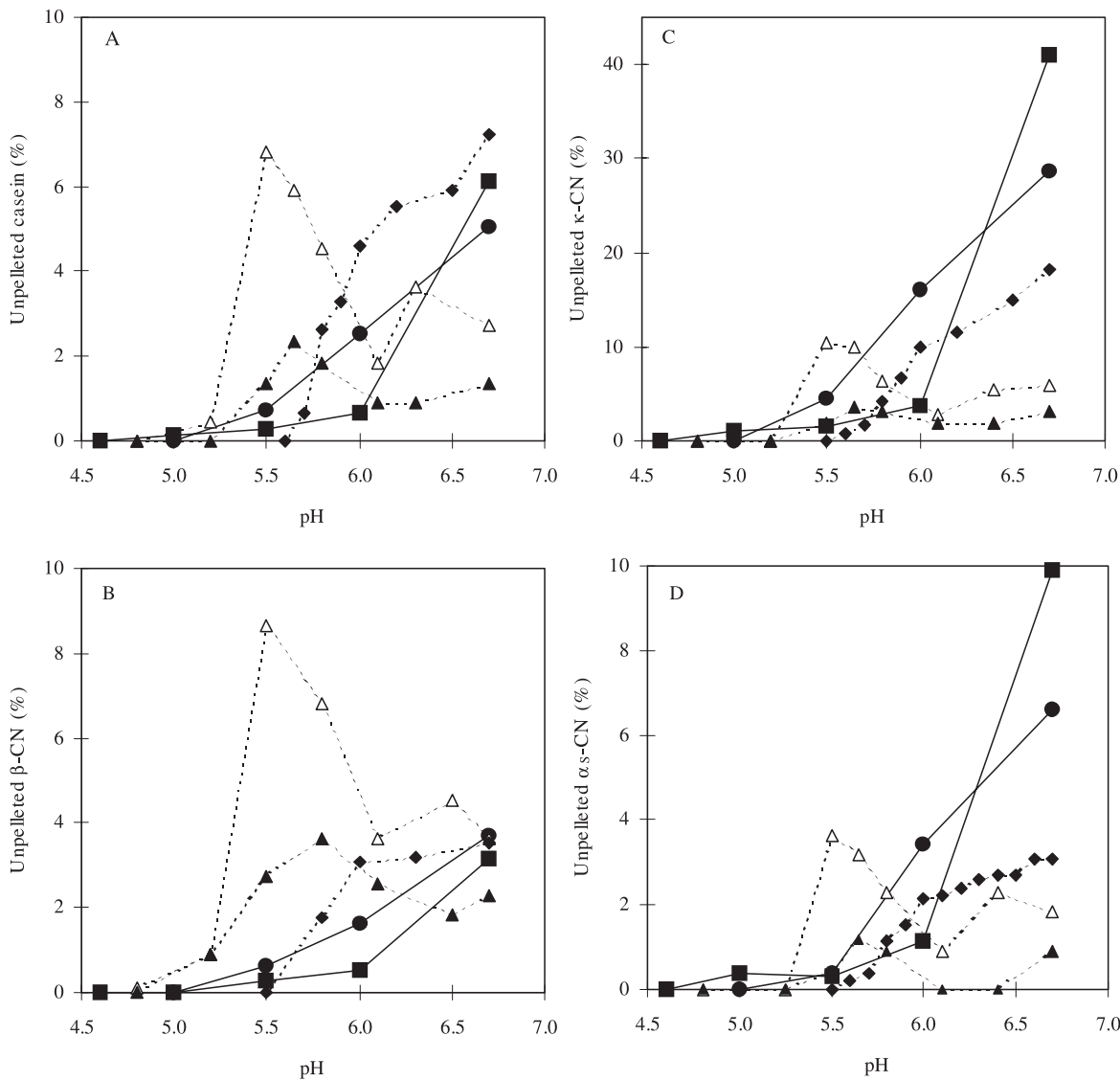

Figure 4. Changes in the amounts of unpelleted caseins as a function of $\mathrm{pH}$ determined with RPHPLC. (A) total casein; (B) $\beta-\mathrm{CN}$; (C) $\kappa-\mathrm{CN} ;$ (D) $\alpha_{\mathrm{S}}-\mathrm{CN}\left(\alpha_{\mathrm{S}_{1}}+\alpha_{\mathrm{S} 2}\right)$. The acidification was carried out at $42{ }^{\circ} \mathrm{C}(\boldsymbol{\bullet})$ or at $30{ }^{\circ} \mathrm{C}(\bullet)$. The $\kappa-\mathrm{CN}$ and $\alpha_{\mathrm{S}}-\mathrm{CN}$ were analysed with DTT, while $\beta-\mathrm{CN}$ was analysed without DTT from the supernatant of ultracentrifugation performed at the fermentation temperature. Mean of 2 replicates. Values from curves in published papers: Law [15] on milk heated at $85{ }^{\circ} \mathrm{C}$ for $10 \mathrm{~min}$ and acidified by GDL at $30^{\circ} \mathrm{C}(\diamond)$; Singh et al. [24] on unheated milk $(\Delta)$ or milk heated at $90{ }^{\circ} \mathrm{C}$ for $5 \min (\mathbf{\Delta})$ and acidified by GDL at $22^{\circ} \mathrm{C}$.

10 min, after acidification with GDL. Many studies reported a dissociation of casein during acidification around $\mathrm{pH} 5.5$ $[6,26,29]$, with a maximum dissociation being dependent on various factors, such as the temperature of acidification or the heat treatment.

There is no difference in the casein content in the supernatant during acidification performed either by GDL or $\mathrm{HCl}$ [6]. This can be explained by the long time which is necessary for the $\mathrm{pH}$-adjustment, which allowed numerous equilibria to take place.

All the caseins were affected by acidification (Fig. 4). At pH 6.6 and $42{ }^{\circ} \mathrm{C}$, unpelleted casein appeared $1 \%$ higher than at $30{ }^{\circ} \mathrm{C}$, but this led to rather small differences in concentrations, lower than $0.3 \mathrm{~g} \cdot \mathrm{L}^{-1}$ in the case of total casein. At $30^{\circ} \mathrm{C}$, a slightly higher concentration of unpelleted $\kappa-\mathrm{CN}$ and $\alpha_{\mathrm{S} 2}-\mathrm{CN}$ was detectable around $\mathrm{pH} 6.2$ (results not shown). 

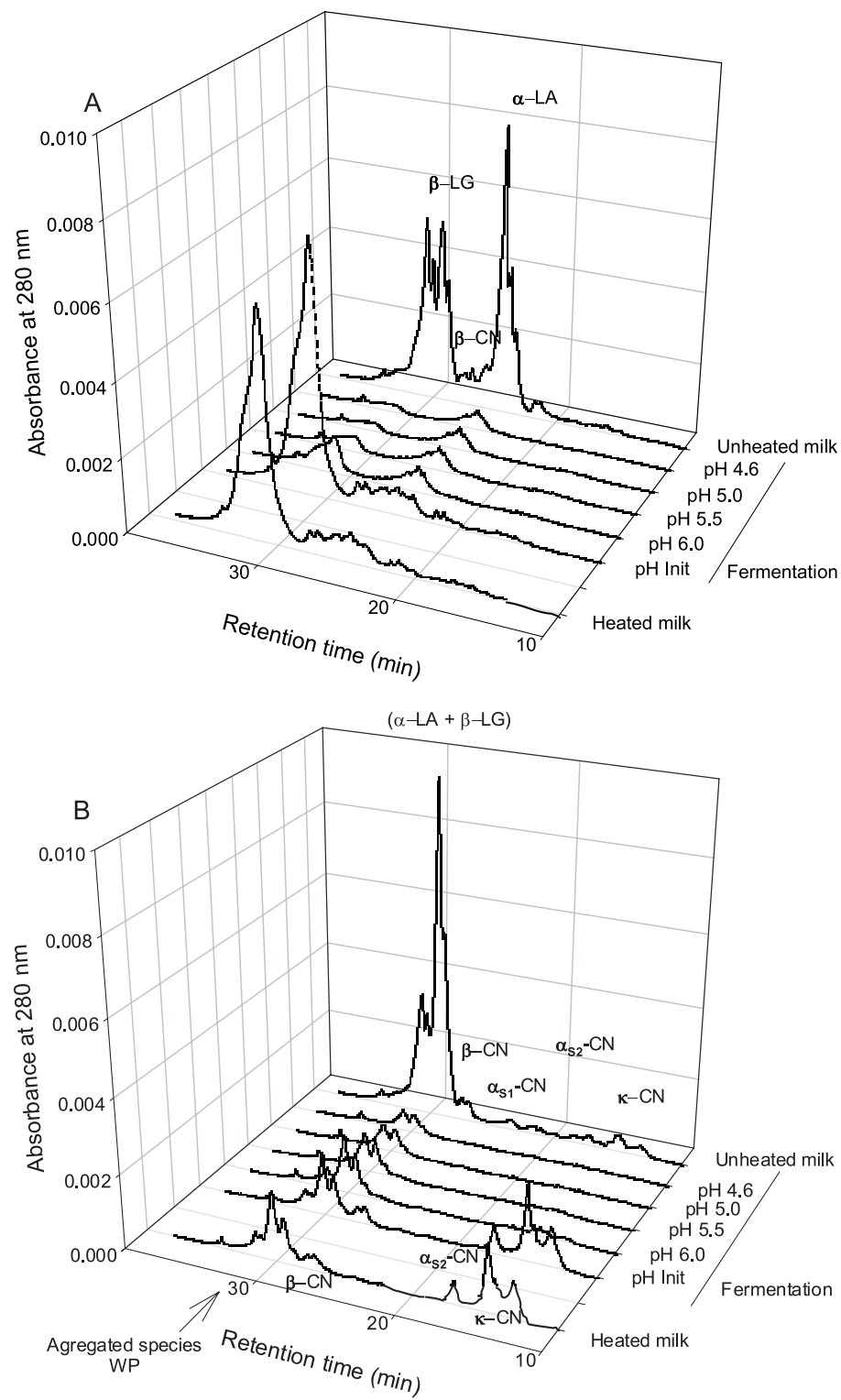

Figure 5. Changes in RP-HPLC elution profile patterns of supernatants for fermented milk as a function of $\mathrm{pH}$. Fermentation was performed at $42{ }^{\circ} \mathrm{C}$ and supernatants were treated in urea buffer without DTT (A) or with DTT (B). Caseins: $\kappa, \alpha_{\mathrm{S} 1}, \alpha_{\mathrm{S} 2}, \beta$. Whey protein: $\alpha$-LA, $\beta$-LG.

A delay of insolubilisation of these caseins during fermentation at $30^{\circ} \mathrm{C}$ can be expected. According to Law [18] and Singh et al. [29], the concentration of casein in the supernatant decreases with an increased temperature of heat treatment and decreases with an increased temperature of acidification. On heat-treated milk, acidified with 
GDL at $30{ }^{\circ} \mathrm{C}$, a progressive decrease of the unpelleted casein with acidification was reported by Law [18], as in the present paper.

It is probable that the pelleted casein behaved like the colloidal salts and that its dissociation was shifted toward lower $\mathrm{pH}$ values. The comparison of the concentration of unpelleted casein during acidification obtained with GDL or bacteria was not performed. As the shift in salt dissociation was observed at $\mathrm{pH}$ lower than 6 , the comparison will probably be difficult, because of the low levels of unpelleted casein at these $\mathrm{pH}$ values and the high standard deviation for the determination of casein concentration compared with that of minerals.

\section{CONCLUSIONS}

This static approach on fermentation of heated milk confirmed that the partition of casein in the pellet fraction has been shifted toward higher $\mathrm{pH}$ values than for unheated milk. The casein behaved like a complex governed by whey protein properties and it can explain the new texture properties of acid gels.

The comparison of calcium partition into diffusible and colloidal fractions between milk acidified by $\mathrm{HCl}$ (or GDL) and fermented milk has pointed out the importance of transfer phenomena between the solvent and the colloidal fractions during acidification, together with the calcium exchangeability inside the casein micelle. These phenomena are probably the slowest, despite the high hydration and porosity of the casein micelle.

It has been suggested that some differences between the outside and the inside of the micelle particle can arise during fermentation. We assumed that, while the outside can be at a $\mathrm{pH}$ where protein-protein interactions can progress and a gel can be formed, the inside is still in a mineralised state. These hypotheses pointed out the possibility for the micelle to present a decreasing $\mathrm{pH}$ gradient from the core to the surface with considerable technological consequences.

As transfer phenomena are suspected to be important, we studied the effect of the temperature at 30 and $42{ }^{\circ} \mathrm{C}$. When the fermentation was carried out at $30{ }^{\circ} \mathrm{C}$ rather than at $42{ }^{\circ} \mathrm{C}$, more casein was present in the unpelleted fraction, while the pelleted casein was more hydrated, but the salt dissociation was similar at both temperatures. We expect that these physicochemical changes of casein will result in modified rheological properties of yoghurt.

\section{ACKNOWLEDGEMENTS}

This work has been partly financed by the Danone Group and Rhodia Food and they are gratefully acknowledged for this and for general discussions.

\section{REFERENCES}

[1] AFNOR-DGCCRF, Determination of the ash content, Reference method, AFNOR NF-V-04-208 (1989) 187-190.

[2] Anema S.G., Klostermeyer H., Heatinduced, $\mathrm{pH}$-dependent dissociation of casein micelles on heating reconstituted skim milk at temperatures below $100{ }^{\circ} \mathrm{C}$, J. Agric. Food Chem. 45 (1997) 1108-1115.

[3] Banon S., Hardy J., Study of acid milk coagulation by an optical method using light reflection, J. Dairy Res. 58 (1991) 75-84.

[4] Banon S., Hardy J., A colloidal approach of milk acidification by glucono-delta-lactone, J. Dairy Sci. 75 (1992) 935-941.

[5] Corredig M., Dalgleish D.G., Effect of temperature and $\mathrm{pH}$ on the interactions of whey proteins with casein micelles in skim milk, Food Res. Int. 29 (1996) 49-55

[6] Dalgleish D.G., Law A.J.R., pH-Induced dissociation of bovine casein micelles. I. Analysis of liberated caseins, J. Dairy Res. 55 (1988) 529-538.

[7] Dalgleish D.G., Law A.J.R., pH-Induced dissociation of bovine casein micelles. II. Mineral solubilization and its relation to casein release, J. Dairy Res. 56 (1989) 727-735.

[8] de Kruif C.G., Skim milk acidification, J. Coll. Interface Sci. 185 (1997) 19-25.

[9] du Parquet H., Influence de l'abaissement du $\mathrm{pH}$ sur les caractéristiques physicochimiques des constituants du lait, Techn. Lait 998 (1985) 44-55. 
[10] Famelart M.H., Lepesant F., Gaucheron F., Le Graet Y., Schuck P., pH-Induced physicochemical modifications of native phosphocaseinate suspensions: Influence of aqueous phase, Lait 76 (1996) 445-460.

[11] Favrot C., Croissance de Lactococcus lactis subsp lactis dans le lait : Effet de la coagulation par la présure, Ph.D. Thesis, École Nationale Supérieure Agronomique de Rennes, 1994.

[12] Gastaldi E., Lagaude A., Tarodo de la Fuente B., Micellar transition state in casein between $\mathrm{pH} 5.5$ and 5.0, J. Food Sci. 61 (1996) 59-68.

[13] Gastaldi E., Lagaude A., Marchesseau S. Tarodo de la Fuente B., Acid milk gel formation as affected by total solids content, J. Food Sci. 62 (1997) 671-675.

[14] Horne D.S., Davidson C.M., Influence of heat treatment on gel formation in acidified milks, in: Protein and fat globule modifications by heat treatment, homogeneization and other technological means for high quality dairy products, Int. Dairy Fed., Brussels, Belgium, special issue 9303 (1993) 267-276.

[15] IDF, Milk, cream and evaporated milk Determination of total solids content. Standard 21B, Int. Dairy Fed. Brussels, Belgium, 1987.

[16] Jaubert A., Martin P., RP-HPLC analysis of goat caseins. Identification of $\alpha_{S 1}$ et $\alpha_{S 2}$ genetic variants, Lait 72 (1992) 235-247.

[17] Kinsella J.E., Fox P.F., Water sorption by proteins: milk and whey proteins, Crit. Rev. Food Sci. Nutr. 24 (1984) 91-139.

[18] Law A.J.R., Effects of heat treatment and acidification on the dissociation of bovine casein micelles, J. Dairy Res. 63 (1996) 35-48.

[19] Law A.J.R., Leaver J., Effects of acidification and storage of milk on dissociation of bovine casein micelles, J. Agric. Food Chem. 46 (1998) 5008-5016.

[20] Le Graet Y., Brulé G., Les équilibres minéraux du lait: Influence du $\mathrm{pH}$ et de la force ionique, Lait 73 (1993) 51-60.

[21] Lucey J.A., Singh H., Formation and physical properties of acid milk gels: a review, Food Res. Int. 30 (1997) 529-542.

[22] Lucey J.A., Teo C.T., Munro P.A., Singh H., Rheological properties at small (dynamic) and large (yield) deformations of acid gels made from heated milk, J. Dairy Res. 64 (1997) 591-600.

[23] Lucey J.A., Tamehana M., Singh H., Munro P.A., A comparison of the formation, rheological properties and microstructure of acid skim milk gels made with a bacterial culture or glucono-delta-lactone, Food Res. Int. 31 (1998) 147-155.
[24] Merck and Co. Inc., The Merck index, 11th edn., Budavari S., O'Neil M.J., Smith A., Heckelman P.E. (Eds.), Merck and Co., Rathway, USA, 1989.

[25] Oldfield D.J., Singh H., Taylor M.W., Pearce K.N., Heat-induced interactions of $\beta$-lactoglobulin and $\alpha$-lactalbumin with the casein micelle in $\mathrm{pH}$-adjusted skim milk, Int Dairy J. 10 (2000) 509-518.

[26] Rose D., Relation between micellar and serum casein in bovine milk, J. Dairy Sci. 51 (1968) 1897-1902.

[27] Rose D., Brunner J.R., Kalan E.B., Larson B.L., Melnychyn P., Swaisgood H.E., Waugh D.F., Nomenclature of the proteins of cow's milk: Third revision, J. Dairy Sci. 53 (1969) 1-17.

[28] Rowland S.J., The determination of nitrogen distribution of milk, J. Dairy Res. 9 (1938) 42-46.

[29] Singh H., Robert M.S., Munro P.A., Teo C.T., Acid-induced dissociation of casein micelles in milk: Effects of heat treatment, J. Dairy Sci. 79 (1996) 1340-1346.

[30] Snoeren T.H.M., Klok H.J., van Hooydonk A.C.M., Damman A.J., The voluminosity of casein micelles, Milchwissenschaft 39 (1984) 461-463.

[31] Sood S.M., Gaind D.K., Dewan R.K., Correlation between micelle solvation and calcium content, N.Z.J. Dairy Sci. Technol. 14 (1979) 32-34.

[32] Spinnler H.E., Corrieu G., Automatic method to quantify starter activity based on pH measurement, J. Dairy Res. 56 (1989) 755-764.

[33] Tarodo de la Fuente B., Alais C., Solvation of casein in bovine milk, J. Dairy Sci. 58 (1975) 293-300.

[34] van Hooydonk A.C.M., The renneting properties of heated milk, Neth. Milk Dairy J. 41 (1987) 3-18

[35] van Hooydonk A.C.M., Hagedoorn H.G., Boerrigter I.J., pH-induced physico-chemical changes of casein micelles in milk and their effect on renneting. 1. Effect of acidification on physico-chemical properties, Neth. Milk Dairy J. 40 (1986) 281-296.

[36] Visser S., Slangen C.J., Rollema H.S., Phenotyping of bovine milk proteins by reversed-phase high-performance liquid chromatography, J. Chromatogr. 548 (1991) 361-370.

[37] Vreeman H.J., van Markwijk B.W., Both P., The structure of casein micelles between $\mathrm{pH}$ 5.5 and 6.7 as determined by light-scattering, electron microscopy and voluminosity experiments, J. Dairy Res. 56 (1989) 463-470. 